Brit. Heart f., 1969, 31, 679.

\title{
Pathogenesis of Primary Abnormalities of the Mitral Valve in Marfan's Syndrome
}

\author{
DORRANCE BOWERS \\ From the Department of Medicine, Kelowna General Hospital, Kelowna, B.C., Canada
}

Marfan in 1896 published a report of a patient with arachnodactyly and dolichocephaly but without ocular or cardiovascular abnormalities. Subsequently, patency of the foramen ovale and atrial septal defects were shown at necropsy in the first three patients with arachnodactyly. Thereafter, atrial septal defects were erroneously considered to be the cardiovascular hallmark of Marfan's syndrome. Baer, Taussig, and Oppenheimer (1943) directed attention to a more common abnormality of the cardiovascular system associated with this syndrome, namely degeneration of the medial layer of the aortic wall. It is now agreed that aortic dilatation, aortic aneurysms, aortic dissection, and aortic valve insufficiency - all related to degeneration of the aortic media - are the most common cardiovascular complications of Marfan's syndrome.

Until the past decade, there has been relatively little interest in mitral valve abnormalities in Marfan's syndrome, though Salle in 1912 had reported wrinkling and translucent thickening of the mitral leaflets in a patient with arachnodactyly. The current interest in the mitral valve of Marfan patients may be related, in part, to improvement in the surgical treatment of mitral insufficiency (Dietzman et al., 1967).

The purpose of this paper is to review the various pathogenetic mechanisms underlying primary abnormalities of the mitral valve in patients with Marfan's syndrome. First, however, the author's criteria for the diagnosis of Marfan's syndrome will be outlined, and the distinction between primary and secondary abnormalities of the mitral valve will be clarified.

The author's criteria for the diagnosis of Marfan's syndrome are presented in Table I; at least one major and one minor criterion should be present. Some patients reported as examples of mitral valve involvement in Marfan's syndrome do not satisfy

Received January 6, 1969.
TABLE I

AUTHOR'S CRITERIA FOR DIAGNOSIS OF MARFAN'S SYNDROME

\begin{tabular}{|c|c|c|}
\hline & Criteria & $\begin{array}{l}\text { Recognition as a feature } \\
\text { of Marfan's syndrome }\end{array}$ \\
\hline Major & $\begin{array}{l}\text { (1) Positive family history } \\
\text { (2) Dislocated ocular lenses } \\
\text { (ectopia lenti) }\end{array}$ & $\begin{array}{l}\text { Familial involvement em- } \\
\text { phasized by Weve } \\
(1931)^{\star} \\
\text { Association of ocular lens } \\
\text { dislocations with arach- } \\
\text { nodactyly recognized by } \\
\text { Börger (1914)^ }\end{array}$ \\
\hline Minor & $\begin{array}{l}\text { (1) Skeletal stigmata, e.g. } \\
\text { arachnodactyly, doli- } \\
\text { chocephaly, pectus } \\
\text { excavatum, kypho- } \\
\text { scoliosis, etc. } \\
\text { (2) Cardiovascular involve- } \\
\text { ment, abnormal accu- } \\
\text { mulation of basophilic } \\
\text { mucoid material re- } \\
\text { placing muscle, colla- } \\
\text { gen, or elastic fibres } \\
\text { (3) Increased urinary excre- } \\
\text { tion of hydroxyproline }\end{array}$ & Noted by Baer et al. (1943) \\
\hline
\end{tabular}

* The familial, ocular, and skeletal features of this syndrome were clearly described by Williams (1876).

these criteria (Tung and Liebow, 1952, Case 1; R. Kreutzer, 1961, personal communication; Edynak and Rawson, 1963; Berenson and Geer, 1963; Read, Thal, and Wendt, 1965; Dietzman et al., 1967). (It must be admitted that the patient described by Marfan (1896) does not meet these diagnostic criteria. Presumably, this is the reason that McKusick (1966) prefers the designation "the Marfan syndrome" to "Marfan's syndrome".)

A common cause of mitral valve abnormalities in patients with Marfan's syndrome is left ventricular hypertrophy and dilatation secondary to aortic valvular insufficiency (Table II). These cause dilatation of the mitral ring, attenuation of the chordae tendineae, and mitral regurgitation with left atrial dilatation. Several Marfan patients with mitral regurgitation and aortic valve insufficiency have been reported (Bowers, 1961, Case 2; 1962; Soulié et al., 1961, Case 1; B. L. Segal et al., 1962, Case 2; Headley, Carpenter, and Sawyer, 1963, Case 1; 
TABLE II

PATHOGENESIS OF MITRAL VALVE ABNORMALITIES IN MARFAN'S SYNDROME

\footnotetext{
A: Abnormalities secondary to aortic valvular or left ventricular disease

B : Primary abnormalities of mitral valve

(1) Gross congenital malformations

(2) Resulting from rheumatic endocarditis

(3) As manifestation of inherent defect in connective tissues of cardiovascular system

C: Resulting from combinations of above-listed pathogenetic mechanisms
}

Bolande, 1963; Bolande and Tucker, 1964, Case B.K.). When structural or functional abnormalities of the mitral valve occur in patients with Marfan's syndrome, the possibility must be considered that these abnormalities are secondary to aortic disease. To ensure that the discussion to follow will be limited to patients with primary abnormalities of the mitral valve, the author has included only those reported Marfan patients in whom significant abnormalities of the aortic valve have been excluded by pathological examination. Thus, omitted from further consideration are those Marfan patients in whom the diagnosis of primary mitral valve disease has been based on clinical findings (D. Kavanagh, 1960, personal communication; Breton et al., 1961; Hardin, 1962; Segal, Kasparian, and Likoff, 1962; Miller, Brown, and Swan, 1964; Wooley et al., 1965a, b: 3 of 4 cases; Perrin et al., 1966; McKusick, 1966: his Fig. 3-37; A. Pasternac, 1967, personal communication; Bittar and Sosa, 1968: Case M.D.; Anderson, Grondin, and Amplatz, 1968; Barlow et al., 1968; Grossman et al., 1968).

\section{Review of Reports Illustrating Pathogenetic Mechanisms Underlying Primary ABNoR- MALITIES OF MITRAL VALVE}

Gross Congenital Malformations. Gross congenital abnormalities of the mitral valve (that is, abnormalities that are present at birth but that are not necessarily genetically determined) are uncommon in patients with Marfan's syndrome. The author is aware of the following congenital anomalies of the mitral valve reported in patients with Marfan's syndrome: (i) an anomalous flap of the mitral valvepatient described and illustrated by McKusick (1966) (his Fig. 3-18C); (ii) three cusps of the mitral valve-patient described by Keith, Rowe, and Vlad (1958); Bowers (1961) (Case 1); Wagenvoort, Neufeld, and Edwards (1962) (Case 3); and described and illustrated by McKusick (1966) (his Fig. 3-6A); and (iii) five cusps of the mitral valve-patient described by McKusick (1966) (his Fig. 3-36). To the author's knowledge, ostium primum defects of the interatrial septum associated with clefts of the atrioventricular valves, transposition of the great vessels associated with abnormal atrioventricular valves, and endocardial fibroelastosis with mitral valve involvement, have not been reported in patients with Marfan's syndrome.

Rheumatic Mitral Valvulitis. The prevalence of rheumatic valvulitis in patients with Marfan's syndrome is difficult to establish. There is no reason to believe that patients with Marfan's syndrome are less susceptible to rheumatic heart disease than are individuals without Marfan's syndrome; at one time, it was suspected (Futcher and Southworth, 1938) that patients with Marfan's syndrome were unusually susceptible to rheumatic fever. If this is correct, it is surprising that mitral stenosis has rarely been proven in a patient with Marfan's syndrome. In addition, to the author's knowledge, Aschoff nodules have not been reported in histological studies of hearts from patients with mitral disease and Marfan's syndrome. The patient reported by Stewart (1939) has been cited as showing mitral stenosis associated with Marfan's syndrome; this patient did not have a family history of Marfan's syndrome, and was not shown to have ocular lens dislocations. Possible examples of rheumatic mitral valvulitis in patients with Marfan's syndrome have been published by Lutman and Neel (1949) (their Patient II 16), and by Miller and Pearson (1959). In the absence of pathological confirmation of the diagnosis, the patient described by Pahwa and Gupta (1962), as an example of Lutembacher's syndrome associated with Marfan's syndrome, cannot be accepted here.

Bacterial Endocarditis. The frequency of involvement of the mitral valve by bacterial endocarditis in patients with Marfan's syndrome is difficult to determine for two reasons. First, it is known (Hepper, Burchell, and Edwards, 1956) that bacterial endocarditis may occur and pass unrecognized during life. Secondly, bacterial endocarditis may be diagnosed and cured in the absence of conclusive evidence that the infection was localized on the mitral valve. At least four examples of bacterial endocarditis on the mitral valve of patients with Marfan's syndrome have been described; the patients reported by Olcott (1940) and by VivasSalas and Sansón (1948), the patient reported (1955) and illustrated (1966) by McKusick (his Fig. 3-35), and the patient reported by Wunsch, Steinmetz, and Fisch (1965). Though bacterial endocarditis may develop on normal valvular and mural endocardium, it is possible that the mitral valves of these patients were abnormal before the endocarditis. One can only speculate on the nature of this prior abnormality because, as Wunsch et al. (1965) emphasized, 
the damage produced by bacterial endocarditis may obscure the underlying pathological process. Miller and Pearson (1959) suggested that their patient had rheumatic heart disease; the author would propose an alternative explanation, namely, that the abnormality preceding the endocarditis was an expression of a fundamental defect in the connective tissues of the cardiovascular system of these patients (vide infra).

\section{A Manifestation of an Inherent Defect in Connective} Tissues of Marfan Patients. Perhaps the most interesting examples of mitral disease in patients with Marfan's syndrome are those cases that cannot be ascribed to any of the pathogenetic mechanisms so far discussed. These cases support the concept that there is a pathogenetic mechanism inherent in Marfan's syndrome. To illustrate this concept, the following cases, already reported, which, in the author's opinion, show no evidence for the previously discussed pathogenetic mechanisms, will be summarized.

\section{Case Reports}

Case 1. A 21-year-old man with a family history of Marfan's syndrome and bilateral lens dislocations and arachnodactyly was reported by Van Buchem (Case 7: 1958; Case 1: 1959). There was no history of rheumatic fever or bacterial endocarditis. This patient had a loud systolic heart murmur.

Necropsy examination showed a normal aortic valve. The mitral valve ring was dilated (circumference $23 \mathrm{~cm}$.). The mitral leaflets were thickened, shiny, and smooth. Microscopical examination of the mitral leaflets showed fibrous thickening.

Case 2. This man, reported by Gordon (1959), was 24 years old at the time of his death. The lens had been surgically removed from his right eye; the left lens was dislocated upwards. He had a pigeon-breast deformity. There was an extensive family history of Marfan's syndrome. There was no history of rheumatic fever or bacterial endocirditis.

A systolic murmur was audible over the praecordium, loudest at the apex and the left sternal border. A thrill was palpable at the apex.

At necropsy the aortic valve was normal; the superior half of the mitral valve was adherent to the endocardial surface of the left ventricle anteriorly, and at the upper margin of this valve there were bony spicules protruding into the ventricular cavity. The margin of the valve showed only moderate thickening. Histological study showed the mitral cusps to be hyalinized and acellular.

Case 3. Favara, Nomura, and Bowden (1963) and Bowden, Favara, and Donahoe (1965) (Case 1) reported the clinical and necropsy findings from a 10-year-old boy with ocular lens dislocations and the skeletal stigmata of Marfan's syndrome. There was no history of rheumatic fever or bacterial endocarditis.
Their patient had a grade 3 pansystolic and a faint mid-diastolic apical heart murmur. No murmur to suggest aortic valvular regurgitation was described.

At necropsy the aortic valve and ascending aorta were slightly dilated. The mitral valve ring was much larger than usual at the patient's age. There was endocardial thickening on the posterior wall of the left atrium. Microscopical examination of the mitral cusps showed abundant, loose, metachromatic-staining tissue, with few collagen fibres and no inflammatory cells.

Case 4. This patient (C.R.) has been reported by Bolande (1963) and by Bolande and Tucker (1964). She was 10 months old at the time of her death. Rheumatic heart disease and bacterial endocarditis are unlikely at this early age. She had dislocated ocular lenses, arachnodactyly, and an inguinal hernia. The clinical findings in relation to her cardiovascular condition were not reported.

The pathological report does not mention any abnormality of the aortic valve. The mitral valve ring was widened. The mitral leaflets were thickened, enlarged, and flaccid. The chordae tendineae were shortened, thickened, and occasionally fused. The endocardial surface of the valve and the entire left atrium appeared thickened, opalescent, and mucoid. Histological examination of the mitral cusps and left atrial wall revealed fibromyxoid thickening of the subendocardium containing lacunae filled with metachromatic amorphous material.

Case 5. This 34-month-old girl was reported by Raghib et al. (1965). She had the skeletal features of Marfan's syndrome and bilateral ocular lens dislocations. There was no history of rheumatic fever or bacterial endocarditis. She had a praecordial systolic murmur and thrill.

At necropsy, the aortic valve was normal. A wide mitral orifice was found. The chordae tendineae were long and thin. There was thickening of the left atrial endocardium consistent with a "jet lesion". Microscopical examination of her mitral leaflets showed that the valvular tissue was loosely arranged with spaces containing mucoid material.

Case 6. This 4-month-old male infant was reported by Shankar et al. (1967). He had the skeletal features of Marfan's syndrome and bilateral ocular lens dislocations. A grade 3/6 holosystolic murmur was heard at the left sternal border and at the apex; a grade $2 / 6$ diastolic flow rumble was present at both lower sternal borders.

At necropsy, the aortic and pulmonary valves were microscopically normal. The tricuspid and mitral valve leaflets were irregular, folded, and thickened; the annulus fibrosus of each valve was thinned and increased in diameter. Microscopical examination of the atrioventricular valves showed fibromyxomatous transformation, with increased amounts of mucopolysaccharide in the leaflets and in the annulus fibrosus of each valve.

\section{Discussion}

Descriptions of the microscopical appearance of the mitral valve leaflets are available for the six 
patients whose case histories have been summarized. In two of the descriptions, acellular thickening of the valve leaflets is noted; the remaining four descriptions refer to a ground substance in the connective tissue of these leaflets described as homogeneous, fibromyxoid, or mucoid in consistency, and as basophilic or metachromatic in colour. This latter appearance is similar, if not identical, to that labelled "cystic medionecrosis" by Erdheim. It has been recognized in the media of the aorta and of the larger arteries, and in the leaflets of the aortic valve of patients with Marfan's syndrome, and may be regarded as a characteristic (though probably not a specific) histological feature of Marfan's syndrome (Layman and Wang, 1968). This same appearance in the mitral leaflets of certain patients with Marfan's syndrome suggests that this abnormality of the mitral leaflets is an expression of the inherent defect in the connective tissue in Marfan patients. Bolande (1963) has presented evidence that this inherent defect in the connective tissues of the cardiovascular system of Marfan patients is an overaccumulation of chondroitin sulphate. "Normal" children may be born with fibromyxomatous valvular changes; in Marfan patients the fibromyxomatous change appears greater than normal.

A similar histological appearance in the mitral cusps has been recorded in patients who have not met the author's criteria for the diagnosis of Marfan's syndrome (Tung and Liebow, 1952: Case 1; Edynak and Rawson, 1963; Read et al., 1965). It is difficult to know how best to classify such cases. There can be no objection to classifying them as formes frustes of Marfan's syndrome.

A similar histological appearance in the mitral leaflets has also been reported in Marfan patients with combined abnormalities of the aortic and mitral valves, e.g. Case B.K. reported by Bolande and Tucker (1964), and cases reported by Wooley et al. (1965a, b); and also in a patient with a congenital malformation of the mitral valve (namely 5 cusps) described by McKusick (1966). Thus, it seems probable that, in patients with Marfan's syndrome, the mitral leaflets are inherently defective to a greater or lesser degree (consistent with individual variation in the expression of a genetic defect). For this reason, the valve is abnormally susceptible to pathological processes which impose an added insult on its leaflets, for example, aortic valvular insufficiency, rheumatic carditis, and bacteraemia. The four patients whose case histories have been summarized and whose mitral leaflets contained metachromatic deposits might be categorized as "pure" examples of genetically-determined primary abnormalities of the mitral valve. Probably more com- monly, mitral valve abnormalities in patients with Marfan's syndrome represent the reaction of inherently defective tissues to acquired stresses.

\section{SUMMARY}

This review has been based on case reports describing patients satisfying strict criteria for the diagnoses of (a) Marfan's syndrome and (b) primary mitral valve abnormalities (that is, not secondary to aortic disease).

These reports illustrate that primary mitral valve abnormalities in patients with Marfan's syndrome may be due to gross congenital malformations, to rheumatic endocarditis, to bacterial endocarditis, to an inherent defect in the cardiovascular tissues of these patients, or to combinations of these pathogenetic processes.

\section{REFERENCES}

Anderson, R. E., Grondin, C., and Amplatz, K. (1968; The mitral valve in Marfan's syndrome. Radiology, 91, 910.

Baer, R. W., Taussig, H. B., and Oppenheimer, E. H. (1943). Congenital aneurysmal dilatation of the aorta associated with arachnodactyly. Bull. Fohns Hopk. Hosp., 72, 309.

Barlow, J. B., Bosman, C. K., Pocock, W. A., and Marchand, P. (1968). Late systolic murmurs and non-ejection ("mid-late") systolic clicks. An analysis of 90 patients. Brit. Heart f., 30, 203.

Berenson, G. S., and Geer, J. C. (1963). Heart disease in the Hurler and Marfan syndromes. Arch. intern. Med., $111,58$.

Bittar, N., and Sosa, J. A. (1968). The billowing mitral valve leaflet. Report on fourteen patients. Circulation, 38, 763.

Bolande, R. P. (1963). The nature of the connective tissue abiotrophy in the Marfan syndrome. Lab. Invest., 12, 1087.

- , and Tucker, A. S. (1964). Pulmonary emphysema and other cardiorespiratory lesions as part of the Marfan abiotrophy. Pediatrics, 33, 356.

Börger, F. (1914). UUber zwei Fälle von Arachnodaktylie. Z. Kinderheilk., 12, 161.

Bowden, D. H., Favara, B. E., and Donahoe, J. L. (1965). Marfan's syndrome. Accelerated course in childhood associated with lesions of mitral valve and pulmonary artery. Amer. Heart F., 69, 96.

Bowers, D. (1961). An electrocardiographic pattern associated with mitral valve deformity in Marfan's syndrome. Circulation, 23, 30.

- (1962). Mitral regurgitation in Marfan's syndrome (Abstract). Circulation, 26, 690.

Breton, A., François, P., LeKieffre, M., Dupuis, C., and LeKieffre, J. (1961). Cardiopathies et syndrome de Marfan. A propos de 10 cardiopathies observées dans un groupe de 52 malades. Arch. Mal. Coeur, 54, 900.

Dietzman, R. H., Peter, E. T., Wang, Y., and Lillehei, R. C. (1967). Mitral insufficiency in Marfan's syndrome. A case report of surgical correction. Dis. Chest, 51, 650.

Edynak, G. M., and Rawson, A. J. (1963). Ruptured aneurysm of the mitral valve in a Marfan-like syndrome. Amer. F. Cardiol., 11, 674. 
Favara, B. E., Nomura, R., and Bowden, D. H. (1963). Marfan's syndrome: accelerated course with lesions of mitral valve and pulmonary artery. (Abstract.) Circulation, 28, 718.

Futcher, P. H., and Southworth, H. (1938). Arachnodactyly and its medical complications. Arch. intern. Med., 61, 693.

Gordon, A. M. (1959). The Marfan syndrome: a study of 5 generations in a Kentucky family. f. Ky med. Ass., 57, 1511.

Grossman, H., Fleming, R. J., Engle, M. A., Levin, A. H., and Ehlers, K. H. (1968). Angiocardiography in the apical systolic click syndrome: left ventricular abnormality, mitral insufficiency, late systolic murmur, and inversion of $\mathrm{T}$ waves. Radiology, 91, 898.

Hardin, C. A. (1962). Successful resection of carotid and abdominal aneurysm in two related patients with Marfan's syndrome. New Engl. f. Med., 267, 141.

Headley, R. N., Carpenter, H. M., and Sawyer, C. G. (1963). Unusual features of Marfan's syndrome including two postmortem studies. Amer. F. Cardiol., 11, 259.

Hepper, N. G. G., Burchell, H. B., and Edwards, J. E. (1956). Mitral insufficiency in healed, unrecognized bacterial endocarditis. Proc. Mayo Clin., 31, 659.

Keith, J. D., Rowe, R. D., and Vlad, P. (1958). Heart Disease in Infancy and Childhood. Macmillan, New York.

Layman, T. E., and Wang, Y. (1968). Idiopathic cystic medionecrosis and aneurysmal dilatation of the ascending aorta. Med. Clin. N. Amer., 52, 1145.

Lutman, F. C., and Neel, J. V. (1949). Inheritance of arachnodactyly, ectopia lentis and other congenital anomalies (Marfan's syndrome) in the E. family. Arch. Ophthal. (Chic.), 41, 276.

McKusick, V. A. (1955). The cardiovascular aspects of Marfan's syndrome: a heritable disorder of connective tissue. Circulation, 11, 321.

(1966). Heritable Disorders of Connective Tissue, 3rd ed. Mosby, St. Louis.

Marfan, A. B. (1896). Un cas de déformation congénitale des quatres membres, plus prononcée aux extrémités, caractérisée par l'allongement des os avec un certain degré d'amincissement. Bull. Soc. méd. Hôp. Paris, 3 ser., 13, 220.

Miller, G. A. H., Brown, R., and Swan, H. J. C. (1964). Isolated congenital mitral insufficiency with particular reference to left heart volumes. Circulation, 29, 356.

Miller, R., and Pearson, R. J. (1959). Mitral insufficiency simulating aortic stenosis. Report of an unusual manifestation of Marfan's syndrome. New Engl. f. Med., 260,1210 .

Olcott, C. T. (1940). Arachnodactyly (Marfan's syndrome) with severe anemia. Amer. F. Dis. Child., 60, 660.

Pahwa, J. M., and Gupta, D. P. (1962). Marfan's syndrome: a review of fourteen cases. Brit. F. Ophthal., 46, 105.

Perrin, A., Gravier, J., Verney, R.-N., Pasternac, A., and Froment, R. (1966). L'insuffisance mitrale au cours du syndrome de Marfan. A propos de cinq observations personelles. Actualités cardiol., 15, 229.

Raghib, G., Jue, K. L., Anderson, R. C., and Edwards, J. E. (1965). Marfan's syndrome with mitral insufficiency.
Amer. F. Cardiol., 16, 127.

Read, R. C., Thal, A. P., and Wendt, V. F. (1965). Symptomatic valvular myxomatous transformation (the floppy valve syndrome): a possible forme fruste of the Marfan syndrome. Circulation, 32, 897.

Salle, V. (1912). UUber einen Fall von angeborener abnormer Grösse der Extremitäten mit einem an Akromegalie erinnernden Symptomenkomplex. F. Kinderheilk., 75, 540.

Segal, B., Kasparian, H., and Likoff, W. (1962). Mitral regurgitation in a patient with the Marfan syndrome. Dis. Chest, 41, 457.

Segal, B. L., Tabesh, E., Imbriglia, J. E., and Likoff, W. (1962). The Marfan syndrome. Necropsy findings in three patients with a review of the cardiovascular complications. Angiology, 13, 444.

Shankar, K. R., Hultgren, M. K., Laver, R. M., and Diehl, A. M. (1967). Lethal tricuspid and mitral regurgitation in Marfan's syndrome. Amer. F. Cardiol., 20, 122.

Sjoerdsma, A., Davidson, J. D., Udenfriend, S., and Mitoma, C. (1958). Increased excretion of hydroxyproline in Marfan's syndrome. Lancet, $2,994$.

Soulié, P., Vernant, P., Corone, P., Caramanian, M., Piton, A., Agar, J., Albou, E., Hayem, F., and Rappaport, R. (1961). Les manifestations cardiovasculaires de la maladie de Marfan (à propos de 8 observations personnelles). Arch. Mal. Coeur, 54, 121.

Stewart, R. M. (1939). A case of arachnodactyly. Arch. Dis. Childh., 14, 64.

Tung, H. L., and Liebow, A. A. (1952). Marfan's syndrome. Observations at necropsy: with special reference to medionecrosis of the great vessels. Lab. Invest., 1, 382.

Van Buchem, F. S. P. (1958). Cardiovascular disease in arachnodactyly. Acta med. scand., 161, 197.

- (1959). Arachnodactyly heart. Circulation, 20, 88.

Vivas-Salas, E., and Sansón, R. E. (1948). Sindrome de Marfan, sin cardiopatia congenita y con endocarditis lenta confirmada por la autopsia. Arch. Inst. Cardiol. Méx., 18, 217.

Wagenvoort, C. A., Neufeld, H. N., and Edwards, J. E. (1962). Cardiovascular system in Marfan's syndrome and in idiopathic dilatation of the ascending aorta. Amer. F. Cardiol., 9, 496.

Weve, H. (1931). Ueber Arachnodaktylie (Dystrophia mesodermalis congenita, Typus Marfan). Arch. Augenheilk., 104, 1.

Williams, E. (1876). Rare cases, with practical remarks. Trans. Amer. ophthal. Soc., 2, 291.

Wooley, C. F., Hosier, D. M., Molnar, W., and Ryan, J. M. (1965a). The etiology of mitral regurgitation: the Marfan syndrome. (Abstract.) Ann. intern. Med., 62, 1070.

—, Molnar, W., Hosier, D. M., Sirak, H. D., and Ryan, J. M. (1965b). Etiology of mitral regurgitation. Marfan's syndrome. (Abstract.) Circulation, 32, Suppl. 2, p. 221.

Wunsch, C. M., Steinmetz, E. F., and Fisch, C. (1965). Marfan's syndrome and subacute bacterial endocarditis. Amer. F. Cardiol., 15, 102 